\title{
Analysis of the variability of sugar beet (Beta vulgaris L) growth during the early stages. I. Influence of various conditions on crop establishment
}

\author{
J Boiffin 1, C Durr 1, A Fleury 2, A Marin-Laflèche 1, I Maillet 3 \\ 1 INRA, Station d'Agronomie de Laon-Péronne, BP 101, 02004 Laon Cedex; \\ 2 INAPG, Chaire d'Agronomie, Route de Thiverval, 78850 Grignon; \\ ${ }^{3}$ INRA, Laboratoire d'Agronomie, Route de Thiverval, 78850 Grignon, France
}

(Received 15 January 1992; accepted 4 April 1992)

\begin{abstract}
Summary - The expansion of the sugar beet leaf canopy tends to be slow in the north of France. This is an important source of loss of yield. This study identifies the main sources of growth variability before competition starts between plants. Field plots were set up for different years and crop establishment conditions (soil types, sowing dates, plastic mulches, sowing depths, tillage operations, cultivars). Growth curves were obtained for each experimental treatment by sampling plants having the same emergence date and the same seedling size index. This index was obtained by measuring the length of the first leaf at a constant thermal time from emergence. Date were fitted to an exponential model in which time was expressed as a thermal time calculated from the emergence date and using soil temperatures. This calculation accounted for most of the differences between soil types, mulch conditions and emergence dates. Aerial biomass varied widely at the end of the exponential period. The variability of growth curves was mainly due to their intercept $\left(W_{o}\right)$, which was strongly correlated with the seedling size index. In 1987 , the seedlings having the largest size at the beginning of the study period had a subsequent RGR which was significantly lower than the others. This could be due to a change in the exponential growth pattern in the latest part of the period studied. The average RGR obtained in 1987 were lower than those obtained in 1988, but the other experimental treatments influenced early growth only through the initial size of seedlings: When growth is not limited by soil nutritional factors, the wide variability in plant aerial biomass before competition is largely due to differences at the beginning of seedling growth, established before the 4-leaf stage.
\end{abstract}

Beta vulgaris $\mathrm{L}=$ sugar beet / exponential growth / crop establishment / seedling size / nonlinear regression

Résumé - Variabilité des courbes de croissance de la betterave sucrière (Beta vulgaris L) au stade jeune. I. Influence de différentes conditions d'implantation. Au nord de son aire de culture, le développement du couvert foliaire de la betterave est assez lent ce qui limite l'interception du rayonnement et la productivité. L'étude vise à identifier les principales sources de variabilité de la croissance précédant le début de la compétition entre plantes. Réalisées au champ en 1987 et 1988, les expérimentations ont consisté à mettre en cuvre une large gamme de conditions d'implantation de la betterave : différents types de sols, dates de semis, modalités de couverture du sol (mulch plastique ou sol nu) et de préparation des lits de semences, profondeurs de semis, cultivars. Pour chaque traitement expérimental, les courbes de croissance sont obtenues en échantillonnant des plantes ayant la même date de levée et appartenant, au stade plantule, à la même classe de taille. Celle-ci est évaluée d'après la longueur de la première feuille, $225^{\circ} \mathrm{C}$.j après émergence. Les mesures de biomasse s'ajustent de façon étroite à un modèle exponentiel où une somme de ${ }^{\circ} \mathrm{C}$.j calculée à partir des températures mesurées dans le sol est substituée au temps chronologique. La variabilité des courbes de croissance obtenues est imputable à l'ordonnée à l'origine du modèle, elle-même fortement liée à la classe de taille. En 1987, les plantules ayant la plus forte taille présentent par la suite un taux de croissance moins élevé, qui pourrait être imputable à un changement de régime de croissance (début d'allocation préférentielle des assimilats aux racines) en fin de période d'étude. Par ailleurs, les pentes ne présentent de variation marquée qu'entre années d'expérimentation. La principale influence des traitements expérimentaux s'exprime à travers la distribution des tailles de plantules. Aussi, en l'absence de facteur limitant hydrique ou nutritionnel, l'importante variabilité des biomasses aériennes constatée à la fin du printemps est fortement héritée des tout premiers stades du développement de la culture, antérieurs à l'apparition de la deuxième paire de feuilles. 


\section{INTRODUCTION}

Sugar beet yield in the north of the Paris basin is mainly limited by the amount of intercepted radiation, as it is throughout the northern part of its cropping area (Scott and Jaggard, 1978; Milford et al, 1980). Low temperatures during early spring slow the initial expansion of foliage, so that much of the large inputs of radiation occurring in May and June are wasted. In this context, the time for maximum interception - corresponding to a leaf are index of 2.5 to 3 - is extremely important for total dry matter accumulation and sugar yield. This time for maximum interception depends on the sowing date, the plant population obtained after emergence, the distribution of emergence dates, and the subsequent growth of young plants.

This paper focusses on early growth, defined as starting from the end of heterotrophic growth and ending when the root/shoot ratio starts increasing. Apart from studies on the influence of seed size (Scott et al, 1974), this part of the growth cycle has received less attention than earlier or subsequent stages. Yet, specific patterns of growth response to environmental factors occur during early growth: individual plants do not compete; leaves and growing points remain close to the soil surface; roots mainly develop in the topsoil which has a heterogeneous structure; water and nutrient requirements remain low, and the young sugar beets are very sensitive to diseases, insects and chemical disorders such as low $\mathrm{pH}$. This lack of knowledge might become an obstacle to the full development of sugar beet growth models, since such models need to be properly set up (Milford et al, 1985b; Day, 1986). It also leads to gaps in the interpretation of field experiments on crop establishment, such as tillage experiments. In these studies, data on seedling growth are seldom collected, although they might provide useful indications on the effects of experimental treatments and the way in which they influence final yields.

The first step required to fill this gap is to assess the variability of early growth in field conditions, and to identify its main determinants using a general descriptive model. Such a model would allow identification of the components of the global variability, each of them corresponding to the parameters and variables specified in the model. The objectives of this research were: i), to test the suitability of the classical exponential model (Blackman, 1919; Watson, 1952) for describing sugar beet early growth in a wide range of field conditions; ii), to investigate the response of the parameters involved in this model to various agronomic factors.

This was performed in field experiments with a wide range of conditions at sowing and in which early growth was monitored in relation to a preliminary characterization and partition of the seedling population obtained after emergence. This approach was chosen on the basis of results obtained by Fleury and Caneill (1984) on sugar beet and similar studies on maize (Fleury et al, 1986; Pommel and Fleury, 1989).

\section{MATERIALS AND METHODS}

\section{Experimental design (table I)}

Field experiments were conducted in 1987 and 1988. In 1987, experiments were carried out at 4 sites, 100$150 \mathrm{~km}$ northeast of Paris. The same commercial seed lot (cv Bingo) was used in all experiments. Sowing dates, soil textures, seedbed structures and sowing depths were compared. Plastic mulch and bare soil were compared in 2 cases. In 1988, the experiment compared 4 cultivars known to behave differently during early growth.

Each experimental plot was $15 \mathrm{~m}$ long $\times 10.80 \mathrm{~m}$ wide (24 rows), containing about 2000 plants. There were no replicates, since the aim of the experiment was to generate variability in different ways and not to measure the effect of a specific treatment. Soil analyses indicated that minor nutrients were not deficient at any site. Each site was fertilized at the usual rate of $120-160 \mathrm{~kg}$ $\mathrm{Nha}^{-1}$, 90-160 kg $\mathrm{P}_{2} \mathrm{O}_{5} \mathrm{ha}^{-1}$, 250-300 kg K $\mathrm{O} \mathrm{ha}^{-1}$.

\section{Observations and measurements}

Air and soil temperature were recorded at hourly intervals, $2 \mathrm{~m}$ above and $0.025 \mathrm{~m}$ below the soil surface respectively. From these data, thermal time was calculated on a daily basis from air (ATT) or soil (STT) temperatures, as:

$$
\sum_{x}^{y}\left\{\left[\left(\sum_{h=1}^{24} T_{h}\right) / 24\right]-b\right\}
$$

where $x$ and $y$ are the initial and final days of the studied period, $h$ is the hour, $T$ the temperature, and $b$ the temperature base. This formula is applicable only if the mean daily temperature does not fall below the base temperature. The convention adopted was $b=0$. All mean daily temperatures were higher than $5^{\circ} \mathrm{C}$.

For all sowing dates and throughout the germination period, the thickness of the upper dry layer of soil never reached the minimum sowing depth. The germi- 
Table I. Experimental design.

\begin{tabular}{|c|c|c|c|c|c|c|c|}
\hline Year and site & $\begin{array}{l}\text { Top soil } \\
\text { texture (clay) } \\
\text { content } \% \text { ) }\end{array}$ & $\begin{array}{c}\text { Sowing } \\
\text { date }\end{array}$ & Cultivar & $\begin{array}{l}\text { Seedbed } \\
\text { structure }\end{array}$ & $\begin{array}{l}\text { Sowing } \\
\text { depth } \\
(\mathrm{cm})\end{array}$ & $\begin{array}{l}\text { Plastic } \\
\text { mulch }\end{array}$ & Code \\
\hline 1987 & & & & & & & \\
\hline Laon & $\begin{array}{l}\text { Sandy loam } \\
(15.8)\end{array}$ & $\begin{array}{c}9 \text { April } \\
" ~ \\
" \\
26 \text { May }\end{array}$ & $\begin{array}{c}\text { Bingo } \\
" 1 \\
" \\
"\end{array}$ & $\begin{array}{l}\text { Fine } \\
\text { Fine } \\
\text { Fine } \\
\text { Fine }\end{array}$ & $\begin{array}{l}2.5 \\
4 \\
4.0 \\
2.5\end{array}$ & $\begin{array}{l}\text { Yes } \\
\text { No } \\
" \\
"\end{array}$ & $\begin{array}{l}\text { L1 } \\
\text { L2 } \\
\text { L3 } \\
\text { L4 }\end{array}$ \\
\hline $\begin{array}{l}\text { Mons en } \\
\text { Chaussée }\end{array}$ & $\begin{array}{l}\text { Silt loam } \\
(19.0)\end{array}$ & $\begin{array}{c}7 \text { April } \\
" \\
" \\
"\end{array}$ & " & $\begin{array}{l}\text { Fine } \\
\text { Coarse } \\
\text { Fine }\end{array}$ & $\begin{array}{l}2.5 \\
" \\
" \\
4.0\end{array}$ & $\begin{array}{l}\text { Yes } \\
\text { No } \\
" \\
"\end{array}$ & $\begin{array}{l}\text { M1 } \\
\text { M2 } \\
\text { M3 } \\
\text { M4 }\end{array}$ \\
\hline $\begin{array}{l}\text { St Pierre } \\
\text { Aigle }\end{array}$ & $\begin{array}{l}\text { Silt loam } \\
(11.7) \\
\text { Silt loam } \\
(18.3)\end{array}$ & 18 April & $"$ & Fine & $\begin{array}{l}2.5 \\
\end{array}$ & $\begin{array}{l}\text { No } \\
\text { " }\end{array}$ & $\begin{array}{l}\mathrm{P} 1 \\
\mathrm{P} 2\end{array}$ \\
\hline Aizecourt & $\begin{array}{l}\text { Calcareous } \\
\text { silty clay loam } \\
(28.5) \\
\text { Silt loam (22.5) }\end{array}$ & 16 April & $"$ & Fine & 2.5 & No & $\mathrm{A} 2$ \\
\hline $\begin{array}{l}1988 \\
\text { Mons en } \\
\text { Chaussée }\end{array}$ & $\begin{array}{l}\text { Silt loam } \\
(17.0)\end{array}$ & 6 April & $\begin{array}{l}\text { Bingo } \\
\text { Aramis } \\
\text { Furia } \\
\text { Tosca }\end{array}$ & $\begin{array}{l}\text { Fine } \\
" ~ \\
" ~\end{array}$ & $\begin{array}{l}2.5 \\
" \\
"\end{array}$ & $\begin{array}{l}\text { No } \\
" \\
" \\
"\end{array}$ & $\begin{array}{l}\text { M5 } \\
\text { M6 } \\
\text { M7 } \\
\text { M8 }\end{array}$ \\
\hline
\end{tabular}

nating seeds were surrounded by dark wet soil having water potentials higher than $-0.1 \mathrm{MPa}$, which were not limiting for germination (Gummerson, 1986). Later observations showed that the whole root system was located in layers with high water availability until the end of the study period.

The emergence date of each individual plant was noted. On the day on which a $S T T$ of $225^{\circ} \mathrm{C}$ days from its emergence date was attained, each plant was classified according to the length of its first true leaf as described by Fleury and Caneill (1984). The relationship between this seedling size index and aerial biomass at that time was calibrated on a subsample of about 140 plants and is shown in figure 1. Five grades, numbered from 1 to 5 , were attributed to plants having first leaf lengths of $0-10,10-20,20-30,30-40$ and $40-50 \mathrm{~mm}$. In 1988, all grades were subdivided into 2 equal subclasses ( $5 \mathrm{~mm}$ amplitude) indexed as $\mathrm{a}$ and $\mathrm{b}$.

Aerial biomass was measured on 4 replicates of 35 plants having the same emergence date and the same seedling size index, at 3-6 sampling dates from $S T T 225$ (4 visible leaves) to $S T T 600^{\circ} \mathrm{C}$ days (about 10 visible leaves). This final sampling time was chosen on the basis of root/shoot biomass measurements indicating a constant ratio of about 0.10 until this stage. Similar results were found by Snyder et al (1979) from 4 to 10 true leaves, Fleury and Caneill (1984), Ferré and Fleury (1990).

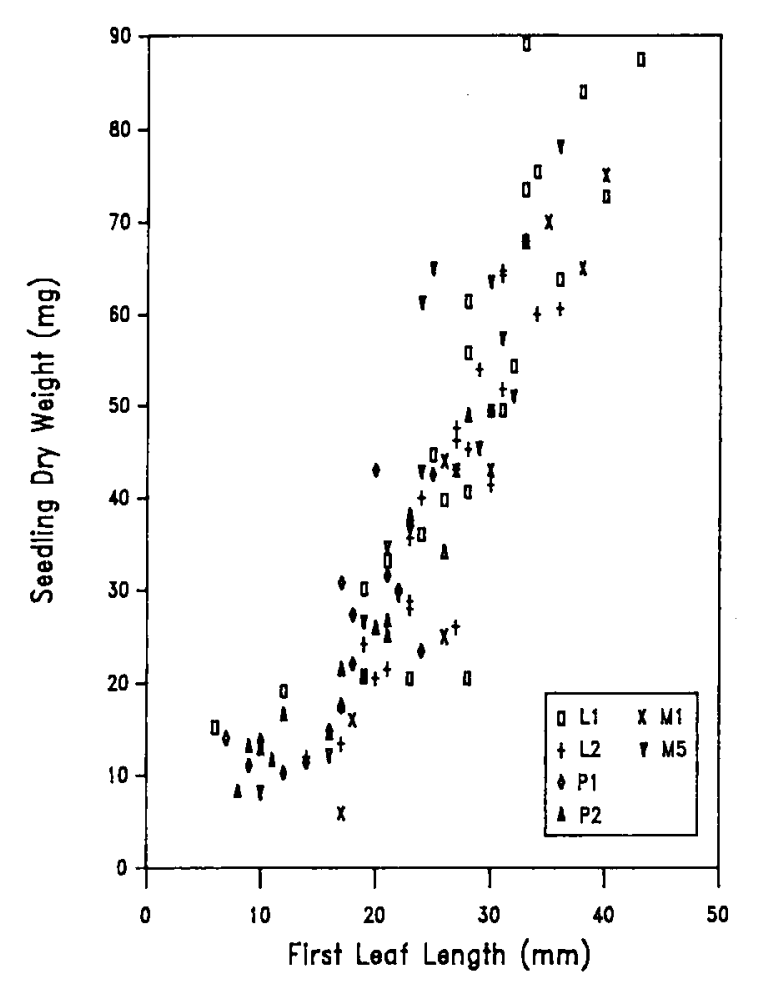

Fig 1. Relationship between the first leaf length and seedling dry weight measured at $S T T=225^{\circ}$ Cdays. Legend refers to table I. 
Only the most represented seedling size grades were sampled from each experimental plot. Since the distributions of seedling size were very different between plots, the sampled grades were not always the same for each experimental treatment.

\section{Growth curve fitting}

Experimental results were fitted to the following exponential model:

$$
W_{t}=W_{o} \exp \left[r\left(t-t_{o}\right)\right]
$$

where $W_{t}$ is the aerial individual dry weight at time $t$, $W_{o}$ is the aerial biomass at $t_{o}$, ie the conventional origin of time, $r$ is the relative growth rate (RGR). The parameters $W_{o}, r$ and $t_{o}$ are assumed to express the effect of internal or external factors controlling the variability of early growth.

The factors controlling the RGR, especially temperature, are not constant under field conditions. Therefore, thermal time (TT) was substituted for chronological time, assuming a linear relationship between RGR and daily mean temperatures. Eq 1 then becomes:

$$
W_{t}=W_{o} \exp \left[k\left(T T_{t}-T T_{t o}\right)\right]
$$

where $k$ is the slope of the relationship between RGR and temperature.

For practical reasons, $t_{o}$ was taken as the emergence date, since this date was known. $W_{o}$ then becomes the value of $W$ obtained by extrabolating the exponential part of the growth curve back to the emergence time. This theoretical value may be different from the actual dry matter at emergence if the growth pattern just after emergence, when photosynthesis is carried out by the cotyledons. is not the same as when the leaves are functioning.

\section{Statistical analysis}

The statistical methods of nonlinear regression were used to estimate the parameters $W_{o}$ and $k$ (Seber and Wild, 1989). The following model is assumed: $Y_{t}=$ $W_{t}+E_{t}$ where $Y_{t}$ is the dry weight at time $t . W_{t}$ is defined by $E_{q} 2$ and $E_{t}$ is an error term. The $E_{t}$ are assumed to be independent, centred Gaussian variables, with variance $\sigma_{t}^{2}$. The variance was assumed to be proportional to the mean square of the biomasses : $\sigma_{t}^{2}=\sigma^{2} W_{t}$. The maximum likelihood estimators of $W_{o}$ and $k$ were calculated using a Gauss-Marauardt algorithm (Messean, 1989), implemented in the library NL (Huet and Messean, 1986).

\section{RESULTS}

\section{Adequacy of the adopted model for describing growth curves}

Growth curves obtained in pairs of situations having the same air temperature and other conditions, but different soil temperatures, were compared (fig 2) to select the most relevant way of calculating the driving variable $\pi T$. As shown in figure 2, the growth curves were distinct when plotted as a function of ATT, but not when STT was the independent variable. Therefore, only soil temperatures were used in further analyses.

The specific effect of emergence date was tested by studying data obtained with treatments L1, L2. L3, for which 3, 5 and 2 emergence dates could be compared, 6 sampling dates being available in each case. The results corresponding to different emergence dates were clearly segregated when biomass was plotted against calendar time (fig $3 a, b, c)$. Conversely, a single relationship was obtained for each treatment when biomass was plotted against thermal time, calculated from the emergence to sampling date (fig $3 \mathrm{~d}, \mathrm{e}, \mathrm{f}$ ). The 3 corresponding regression equations were estimated. Variance analyses of residuals calculated from these equations showed no significant effect of emergence date in 2 cases and a significant but very slight effect in the case of L1. On the basis of these results, the following studies were performed by grouping the results for different emergence dates in a sin-
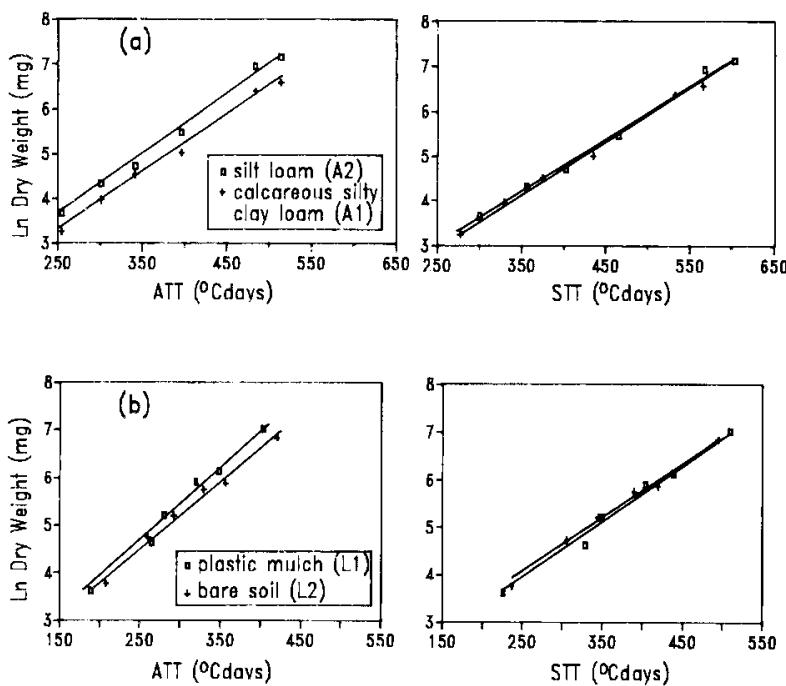

Fig 2. Growth curves with time expressed as $A T T$ or $S T T$ for experimental plots A1-A2 (a) and L1-L2 (b). 

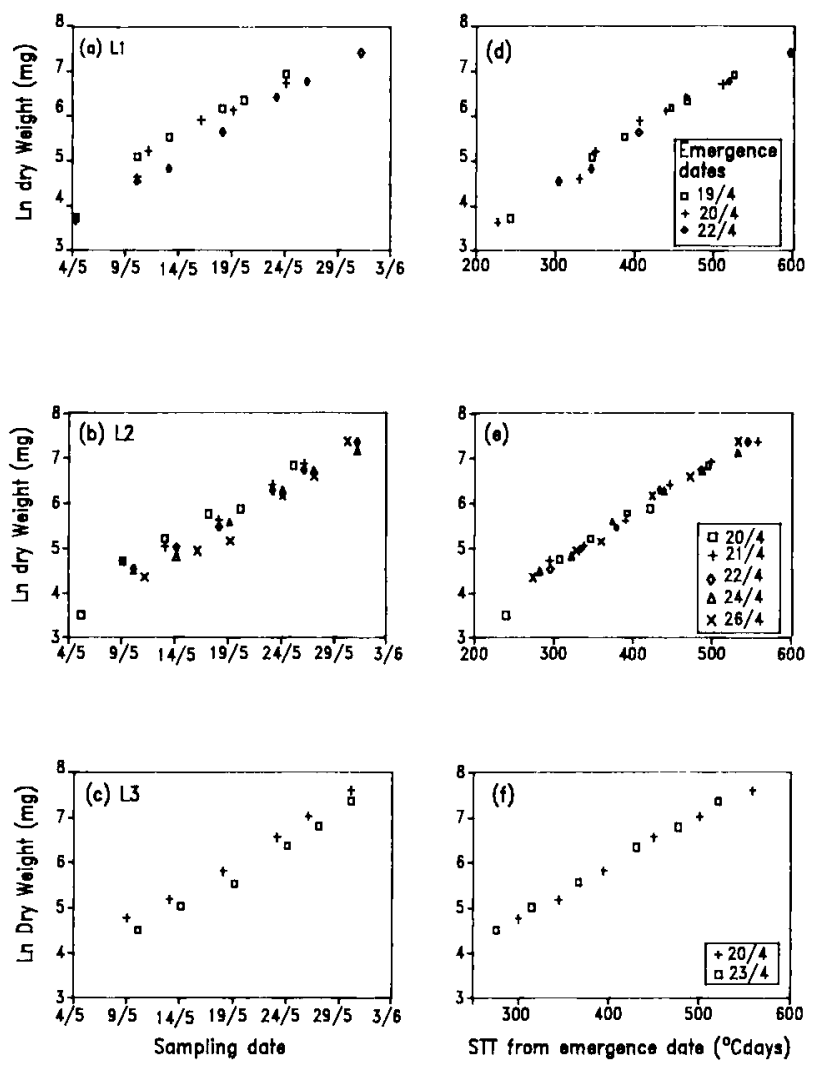

Fig 3. Growth curves for different emergence dates, with time expressed as calendar time $(a, b, c)$ or thermal time $(d, e, f)$.

gle growth curve, with time expressed as thermal time from emergence to the sampling date. This allowed each growth curve to be established on the basis of 6 to 30 sampling dates.

According to this procedure, 33 growth curves could be compared (21 in 1987, 12 in 1988), each corresponding to a given experimental plot and seedling size grade. 29 determination coefficients $R^{2}$ (calculated from correlations between observed and estimated results) had values larger than 0.9. Residuals appeared to be randomly distributed. This was true even for curves having smaller $R^{2}$ values, except for one case where $R^{2}=0.75$ (L4, size grade 3 ). This growth curve exhibited a disruption (not shown) corresponding to a period with very warm air and soil temperatures. This curve was not included in subsequent analyses.

\section{Growth curve comparison}

Table II give the values of $W_{o}$ and $k$ for each growth curve. The range for $W_{o}$ was $0.91-9.69$ $\mathrm{mg}$ for 1987 and $1.38-5.03$ for 1988 . Variations in $W_{o}$ were closely correlated with the seedling size index, but the values of $W_{o}$ for a given grade still varied widely in 1987 . In 1988, when size grades were subdivided, the values of $W_{0}$ were still ordered between grades and more homogeneous within a grade. This indicated that the within-grade variablity in 1987 was partly due to the width of size grades. The results obtained for a given size grade in 1987 and 1988 were consistent.

The values of $k\left(x 1^{2}\right)$ were $1.00-1.26$ for 1987 and $1.16-1.32$ for 1988 . For each year, most of the confidence intervals overlapped (not shown), and there was no systematic pattern of variation in terms of experimental treatments. However, in 1987, $k$ estimations decreased from size grades 1-2 to size grade 4 .

These tendencies were confirmed by a variance analysis (table III). In 1987, the significant effect of experimental treatments on $W_{o}$ corresponded mainly to a contrast between sites $M$ and $P$, and could be related to contrasting size grade distributions at these 2 sites: plants with size grade 4 were frequent at site $M$, and many plants with size grade 3 had first leaf lengths close to the upper limit of this grade. The reverse situation was true on site $P$. The effect of experimental treatment was no longer significant when the size grades were subdivided (1988). The only significant effect on $k$ was related to size grades in 1987. The contrast between grade 4 and grades $2-3$ was significant.

Figure 4 shows that seedling size grade was the dominant factor controlling the distribution of experimental data, once the effect of STT was taken into account. In 1987 the segregation between size grades was a little less marked at the end of the study period. Finally, a single growth curve for each year and size grade (table IV) can be established to summarize all the data.

\section{DISCUSSION}

\section{Modelling early growth in sugar beet}

Our results indicate that the early growth of sugar beet plants having between 4 and 10 visible leaves is adequately described by a simple model derived from the classical exponential model. The basic hypothesis of a constant RGR requires i) a constant rate of dry matter partition between the different organs, and ii) no fluctua- 
Table II. Estimated values of the exponential model parameters $W_{o}(\mathrm{mg})$ and $k\left({ }^{\circ} \mathrm{C} \mathrm{day}-1 \times 10^{2}\right)$ obtained for each growth curve.

\begin{tabular}{|c|c|c|c|c|c|c|c|c|c|c|}
\hline \multirow{3}{*}{ Year } & \multirow{3}{*}{ Site } & \multirow{3}{*}{ Code } & \multicolumn{8}{|c|}{ Seedling size grade } \\
\hline & & & \multicolumn{2}{|c|}{1} & \multicolumn{2}{|c|}{2} & \multicolumn{2}{|l|}{3} & \multicolumn{2}{|l|}{4} \\
\hline & & & $w_{0}$ & $k$ & $W_{0}$ & $k$ & $w_{0}$ & $k$ & $w_{0}$ & $k$ \\
\hline \multirow[t]{13}{*}{1987} & Laon & L1 & & & 1.17 & 1.26 & 2.99 & 1.14 & 6.95 & 1.07 \\
\hline & & $\mathrm{L} 2$ & & & 1.17 & 1.23 & 3.75 & 1.12 & 7.18 & 1.04 \\
\hline & & L3 & & & 1.37 & 1.22 & 3.37 & 1.17 & 6.66 & 1.09 \\
\hline & Mons en & M1 & & & & & 5.97 & 1.01 & 9.69 & 1.00 \\
\hline & Chaussée & M2 & & & & & 5.32 & 1.10 & & \\
\hline & & M3 & & & & & 4.42 & 1.11 & & \\
\hline & & M4 & & & & & 2.97 & 1.22 & & \\
\hline & St Pierre & P1 & & & 1.31 & 1.17 & 1.94 & 1.18 & & \\
\hline & Aigle & $\mathrm{P} 2$ & & & 1.49 & 1.15 & 1.88 & 1.18 & & \\
\hline & Aizecourt & A1 & 0.91 & 1.16 & & & & & & \\
\hline & & $\mathrm{A} 2$ & 0.92 & 1.19 & & & & & & \\
\hline & & & \multicolumn{2}{|c|}{$2 a$} & \multicolumn{2}{|c|}{$2 b$} & \multicolumn{2}{|c|}{$3 a$} & \multicolumn{2}{|c|}{$3 b$} \\
\hline & & & $w_{0}$ & $k$ & $w_{0}$ & k & $w_{0}$ & $k$ & $w_{0}$ & k \\
\hline \multirow[t]{4}{*}{1988} & Mons en & M5 & & & 2.84 & 1.21 & 3.76 & 1.21 & 5.03 & 1.19 \\
\hline & Chaussée & M6 & & & 2.73 & 1.16 & 2.99 & 1.24 & & \\
\hline & & M7 & 1.38 & 1.28 & 2.42 & 1.22 & 3.11 & 1.26 & 4.57 & 1.23 \\
\hline & & M8 & 1.44 & 1.31 & 1.89 & 1.32 & 3.23 & 1.25 & & \\
\hline
\end{tabular}

tion of the environmental factors actually controlling the individual growth rates.

In the case of sugar beet at a vegetative stage, the first condition is approximately satisfied as long as the shoot growth is dominant (Snyder et al, 1979; Fleury and Caneill, 1984; Ferré and Fleury, 1990).

When water and nutrient are plentiful, which is generally the case in the early stages, the environmental factors controlling plant growth are temperature and light. In early spring, the amount of radiation intercepted is strongly limited by leaf area, which is variable and mainly controlled by temperature, both through leaf production and leaf expansion (Milford et al, 1985a). The values of incident radiation in early spring $\left(15-20 \mathrm{MJm}^{\left.-2 \cdot \mathrm{d}^{-1}\right)}\right.$ are high relative to temperature (about $10-15^{\circ} \mathrm{C}$ ), leading to light saturation during some part of the day (Milthorpe and Moorby, 1974). Consequently, it can be assumed that changes in temperature will have more influence than changes in light during the early stages, resulting in a strong correlation between RGR and temperature. As temperature fluctuates in field conditions, early growth is not a direct exponential function of time. The substitution of thermal time for chronological time is a classical method of predicting phenological development (Derieux and Bonhomme, 1982; Durand et al, 1982). In the case of sugar beet, thermal time has also been used by Gummerson (1986) to predict germination, and by Milford et al (1985b) to predict 
Table III. Results of 2-way analysis of variance on estimated growth curve parameters.

\begin{tabular}{|c|c|c|c|c|c|c|c|}
\hline \multirow[b]{2}{*}{ Year } & \multirow[b]{2}{*}{ Factor } & \multicolumn{5}{|c|}{ Parameter } & \multirow[b]{2}{*}{ Sign level 2} \\
\hline & & F ratio & $\underset{d f}{W}$ & Sign level 2 & F ratio & $\begin{array}{r}k \\
d f\end{array}$ & \\
\hline \multirow[t]{2}{*}{19871} & Size grade & 102.6 & 2 & 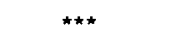 & 9.2 & 2 & $\star \star$ \\
\hline & $\begin{array}{l}\text { Experimental } \\
\text { treatment }\end{array}$ & 9.2 & 8 & $* * *$ & 2.1 & 8 & NS \\
\hline \multirow[t]{2}{*}{1988} & Size grade & 46.2 & 3 & 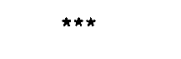 & 0.6 & 3 & NS \\
\hline & $\begin{array}{l}\text { Experimental } \\
\text { treatment }\end{array}$ & 3.3 & 3 & NS & 2.7 & 3 & NS \\
\hline
\end{tabular}

${ }^{1} \mathrm{~A} 1$ and A2 (size grade 1) excluded, because of an excessively unbalanced structure of results. ${ }^{\star \star \star \star}: P \leq 0.01 ;{ }^{\star \star}: P \leq 0.05 ;$ NS: $P$ $>0.10$.

leaf expansion. Applying this approach to growth fitting requires a linear relationship between $R G R$ and temperature. A linear relationship was found over the range $5-20^{\circ} \mathrm{C}$ for net assimilation of sugar beet leaves (Fick et al, 1975) and for leaf expansion (Milford et al, 1985a). All the experimental conditions in the present study met this requirement, except in the case of the latest sowing date (26 May 1987; L4 in table I), for which the mean air temperatures exceeded $20^{\circ} \mathrm{C}$ on some days. Thermal time incorporating soil temperature, measured close to the soil surface, seemed to be more relevant for growth prediction than the thermal time usually calculated with air temperature. During this period, the growing point and young leaves are located close to the soil surface, where steep thermal gradients occur. Growth is also partially controlled by root temperature (Brouwer et al, 1973; Mac Adams and Hayes, 1981). Similar conclusions were reached for predicting the early growth of maize (Allmaras et al, 1964; Watts, 1973; Durr et al, 1990).

The description of growth as an exponential function of thermal time ceases to be acceptable around the 10-leaf stage. Alterations in the growth pattern occur at this time: since there is mutual shading of neighbouring plants, NAR becomes dependent on LAI, and preferential allocation to the root begins. Ferré and Fleury (1990) found a sharp increase in root/shoot ratio correlated with a decrease in RGR when total dry weight per plant reached a threshold value. According to these authors, this value was the same for a given year, whatever the seedling size, but varied widely (2-9 g) between years and sowing dates corresponding to contrasting climatic conditions. In the present study, this threshold value may have been reached for the late sampling dates in 1987 , especially by the largest plants.
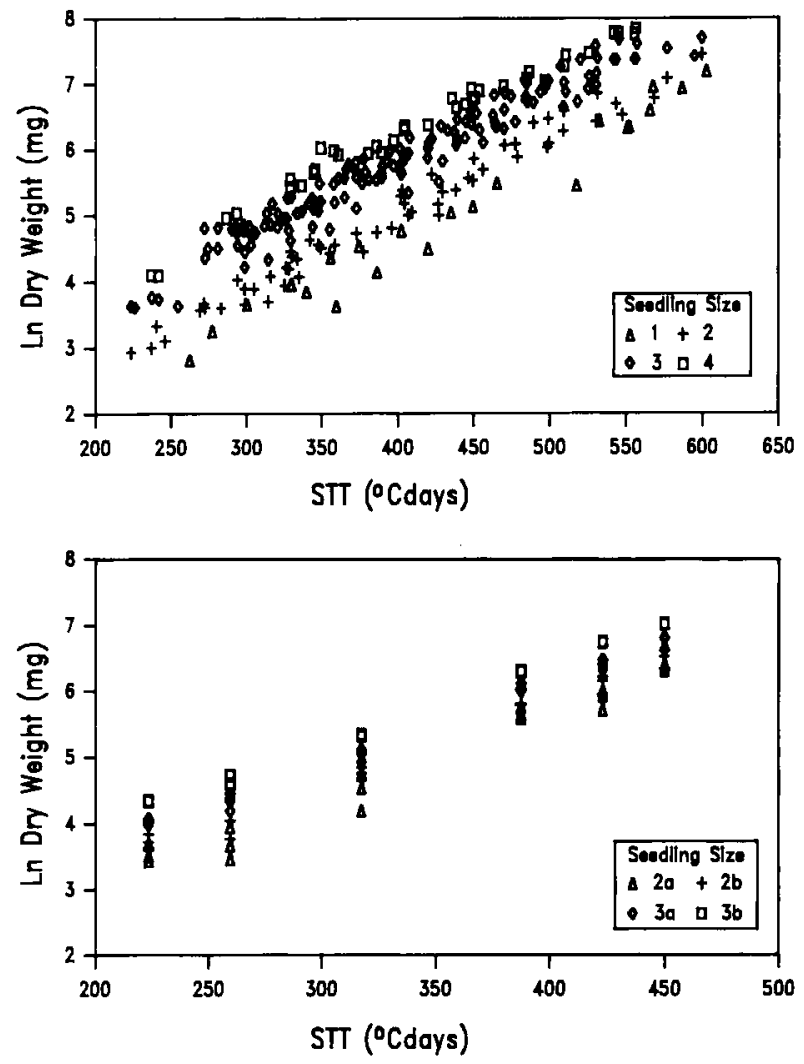

Fig 4. Distribution of plant biomasses as influenced by $S T T$ and seedling size grades. Each point corresponds to the mean biomass of 4 replicates. 
Table IV. Estimated values of the exponential model parameters $W_{o}(\mathrm{mg})$ and $k \times 10^{-2}\left({ }^{\circ} \mathrm{C} \mathrm{d}^{-1}\right)$ obtained for each seedling size grade.

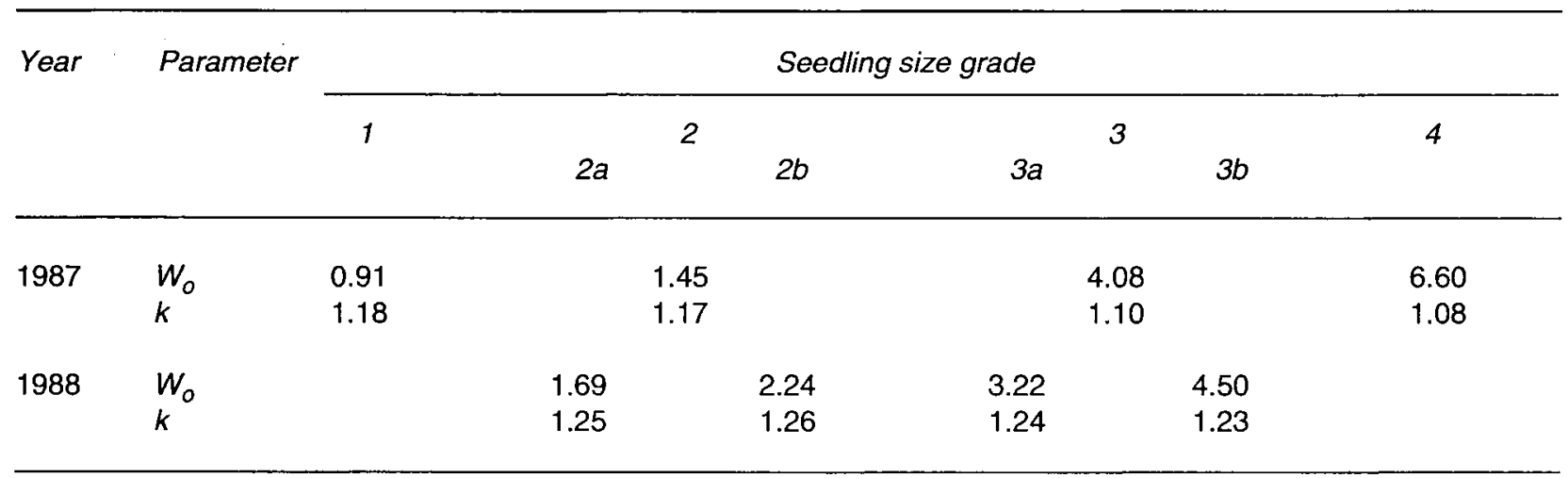

Models for later growth are no longer based on an exponential function and specifically take into account the increase in LAI and incident light interception (Milford et al, 1985b; Day, 1986).

\section{Analysis of early growth variability}

The exponential model previously tested allows 4 components of this variability to be distinguished: the driving variable $S T T$ and the parameters $W_{o}, t_{o}$ and $k$. Considering the average values and usual ranges of variation of these variables and parameters, a simple simulation (table V) shows that the results of early growth at a given time are similarly sensitive to each of these components.

The driving variable STT is the result of climatic conditions and soil characteristics modifying heat transfer in topsoil layers. Mulches and surface reflectance have a great influence, but any modification of topsoil structure or moisture state can also affect the growth of young plants through this variable.

$W_{o}$ expresses the effect of initial seedling size on early growth. The measured size of sugar beet seedlings varied greatly, shoot dry weight at the 4-leaf stage ranged from $10-90 \mathrm{mg}$. This early variability is a major source of plant-toplant heterogeneity at the beginning of competition and of sugar accumulation in roots, because the exponential pattern of growth maintains the biomass ratios between plants of different sizes. Seedling size has been particularly studied in relation to seed characteristics. For sugar beet, Scott et al (1974) found a positive influence of seed size on seedling weight. Similar results have been found for other species, including ce- reals (Carver, 1977), maize (Abd El Rahman and Bourdu, 1986), vegetables (Austin and Longden, 1967; Benjamin, 1984, 1987) and clover (Black, 1956, 1957). Environmental factors, acting either before or after emergence, may also be responsible for part of the seedling size variability. This will be discussed in a further paper.

The parameter $t_{o}$ is directly related to the emergence time. In the usual conditions of crop establishment, delays of 10 days or more (100$150^{\circ} \mathrm{C}$ d) are commonly observed between early

Table V. Influence of changes in the characteristics of sugar beet establishment on biomass attained at a given date.

Modified characteristic

Biomass ratio (Modified/ reference) ${ }^{1}$

Plant density 0.65

(85 000 plants ha-1)

Mean soil temperature $\left(13^{\circ} \mathrm{C}\right)$

Seedling size grade

$100 \%$ grade 2

$100 \%$ grade 4

Emergence date

(7 days later)

0.32

RGR

$\left(k=1.20 \times 10^{-2}{ }^{\circ} \mathrm{C}\right.$ day $\left.^{-1}\right)$

1.35

\footnotetext{
1 The reference biomass per unit area is $50.3 \mathrm{mg} \mathrm{m}^{-2}$ corresponding to: 130000 plants ha-1; $100 \%$ plants having seedling size grade $3\left(W_{o}=3.9 \mathrm{mg}\right) ; k=1.15 \times 10^{-2}{ }^{\circ} \mathrm{C}$ day ${ }^{-1}$; $S T T=600^{\circ} \mathrm{C}$ days with daily mean of soil temperature $=$ $14^{\circ} \mathrm{C}$.
} 
and late emergence in the same field (Duval and Boiffin, 1990). Such differences in the time for starting photosynthesis are also liable to generate a large variability of growth states at the beginning of competition. Moreover, emergence delay and seedling size distributions are not independent (Durr et al, 1992). But once the seedling size and the thermal time from emergence are known, no other influence of emergence date can be detected.

The parameter $k$ expresses the effect of all internal or external factors on the RGR and its response to temperature. In our experiments, the sampling method used was unsuitable for showing plant-to-plant variability of this parameter. On the other hand, it was possible to compare a great number of $k$ parameters obtained over a wide range of conditions at sowing. These comparisons were made with great care to avoid confusing effects, since the influence of sowing date, time for emergence, soil temperature and seedling size were taken into account by the sampling design or by the model used. In the light of these precautions, it is striking that only limited sources of variability of $k$ were revealed, namely the seedling size and the year of experimentation.

The significantly lower values of $k$ obtained for high seedling size grades in 1987 and not in 1988 may be related to the fact that the last sampling dates corresponded to much higher STT and biomass in 1987 than in 1988 (fig 4). Consequently, the largest plants could have reached the threshold value of total biomass previously mentioned (root/shoot ratio starting to increase), while smaller plants might not have reached it. As a result, the RGR of the largest plants would have begun to decrease, leading to a lower overall estimation of $k$. This assumption cannot be directly tested, because root/shoot ratio were not measured on a sufficient number of plants per seedling size. The residual variability of growth curves (fig 4) is also too large to detect a departure from linearity in the relationship between $L n$ dry weight and $S T T$ at the end of the study period. For $S T T$ over $500^{\circ} \mathrm{C}$ d, the frequency of negative residuals was slightly higher for seedling size grades 3 and 4 than for size grades 1 and 2, but this difference (50-35\% respectively) was not statistically significant.

The between-year differerices in $k$ might be partly explained by the same hypothesis. However, some direct environmental influence is not excluded. Apart from temperature, RGR is assumed to be influenced by water shortage, nutrient deficiency, and by the occurrence of physical or chemical disorders such as a temporary oxygen deficiency or a sudden drop in $\mathrm{pH}$. Such problems were not detected in our experiments, except in the case of the latest sowing date in 1987 (treatment L4) for which a mild water stress may have occurred for a few days associated with high temperatures, as previously mentioned. These problems are not major sources of variability in the early stages in common agricultural situations within the context studied. However, they could have generated some yearto-year variability of $k$. The fact that temperature and radiation are not correlated in the same way from one site to another, or from one sowing date to another, may be another possible cause.

In contrast, changes in the physical environment of the seeds and seedlings, induced by the usual variability of seedbed preparation and seed placement, do not seem to significantly modify the RGR. The fact that no difference in $k$ was observed between 4 contrasted cultivars or between different seedling size grades also suggests that this parameter expresses an invariant characteristic of sugar beet behaviour, and probably of most $\mathrm{C} 3$ species in optimal conditions (Greenwood et al, 1977; de Wit et al, 1979).

\section{CONCLUSION}

The early growth of sugar beet is well described by an exponential model in which thermal time is substituted for chronological time. In our experimental conditions, this pattern was observed from the 4 to the 10 leaf stages. Changes affecting the time at which interplant competition begins or at which sugar starts to accumulate in the roots will modify the end of this exponential period.

Various conditions at sowing, including different cultivars, do not affect the slope parameter of this model. These conditions did not include water shortage, marked nutrient deficiency, water excess or low $\mathrm{pH}$. Such accidents would modify the RGR of young sugar beet plants, but are not very frequent during spring in the northern Paris basin.

Differences in seedling size measured at the 4-leaf stage are expressed by corresponding variations in the intercept of the model. Since sugar beet seedling size is very heterogeneous even within a given field, it induces a wide range of plant-to-plant variability at the end of the ex- 
ponential growth period. Conversely, this means that much of the growth variability observed in late June, within or between sugar beet fields, is inherited from the very early stages of crop development.

Except in drastic practices or circumstances, most techniques affecting sugar beet establishment should be mainly evaluated through their effects on: i) soil temperature and then thermal time; ii) the distribution of emergence dates; and iii) the distribution of seedling size. This implies detailed observations and measurements during the initial stages of crop establishment. Comparisons of biomass made on bulked samples will give little information about the influence of a given experimental treatment because different sources of variability cannot be distinguished.

Further stages in the study of the early growth of the sugar beet will consist of analyzing the response of seedling size and emergence delay to environmental factors controlled by tillage and drilling operations.

\section{REFERENCES}

Abd El Rahman N, Bourdu R (1986) Effet de la taille et de la forme des grains sur quelques caractéristiques du développement du maïs au stade jeune. Agronomie 6, 181-186

Allmaras RR, Burrows WC, Larson WE (1964) Early growth of corn as affected by soil temperature. Soil Sci Soc Am Proc 28, 271-275

Austin RB, Longden PC (1967) Some effects of seed size and maturity on the yield of carrot crops. $J$ Hortic 42, 339-353

Benjamin LR (1984) The relative importance of some different sources of plant-weight variation in drilled and transplanted leeks. J Agric Sci Camb 103, 527537

Benjamin LR (1987) The relative importance of cluster size, sowing depth, time of seedling emergence and between-plant spacing on variation in plant size in red beet (Beta vulgaris L) crops. J Agric $S c i$ Camb 108, 221-230

Black JN (1956) The influence of seed size and depth of sowing on preemergence and early vegetative growth of subterranean clover (Trifolium subterraneum L). Aust J Agric Res 7, 98-109

Black JN (1957) Seed size as a factor in the growth of subterranean clover (Trifolium subterraneum $L$ ) under space and sward conditions. Aust $J$ Agric Res 8, 335-351

Blackman VH (1919) The compound interest law and plant growth. Ann Bot 33, 353-360
Brouwer R, Kleinendorst A, Locher JT (1973) Growth response of maize plants to temperature. In: Plant Response to Climatic Factors. Proc Uppsala Symp UNESCO 169-174

Carver MF (1977) The influence of seed size on the performance of cereals in variety trials. J Agric Sci Camb 89, 247-249

Day W (1986) A simple model to describe variation between years in the early growth of sugar beet. Field Crop Res 14, 213-220

Derieux M, Bonhomme R (1982) Heat unit requirements for maize hybrids in Europe. Results of the European FAO subnetwork. I. Sowing-silking period. Maydica 23, 59-77

Durand R, Bonhomme R, Derieux M (1982) Seuil optimal des sommes de températures. Application au maïs (Zea mays L). Agronomie 2, 589-597

Durr C, Boiffin J, Boizard H (1990) Influence du régime thermique sur la croissance pondérale et le rythme d'apparition des feuilles de jeunes plantes de maïs. In : Physiologie et Production du Maïs. AGPM-INRA, 83-89

Durr C, Boiffin J, Fleury A, Coulomb I (1992) Analysis of the variability of sugar beet (Beta vulgaris $L$ ) growth during the early stages. II. Factors influencing seedling size in field conditions. Agronomie 12, 527-535

Duval Y, Boiffin J (1990) Influence of soil crusting on the emergence of sugar beet seedlings. Proc 1st Cong Eur Soc Agron S3P11

Ferré F, Fleury A (1990) Some results on the early growth of sugar beet. Proc 1st Congr Eur Soc Agron S1P59

Fick GW, Loomis RS, Williams WA (1975) Sugar beet. In: Crop Physiology (Evans LT, ed) Cambridge Univ Press, Cambridge, 259-295

Fleury A, Caneill J (1984) Croissance et développement de la betterave sucrière. Analyse de I'hétérogénéité du peuplement. In: Physiologie de la Plante Entière, INRA Agronomie 201-212

Fleury A, Bertrand M, Ronsin T (1986) Essai d'analyse climatique de la croissance précoce du maïs. $C A$ Acad Agric Fr 72, 591-602

Greenwood DJ, Cleaver TJ, Loquens SMH, Niendorf KB (1977) Relationship between plant weight and growing period for vegetable crops in the United Kingdom. Ann Bot 41, 987-997

Gummerson RJ (1986) The effect of constant temperatures and osmotic potentials on the germination of sugar beet. J Exp Bot 37, 729-741

Huet S, Messean A (1986) NL: a statistical package for several nonlinear regression problems. In: Proc Computational Statistics (De Antoni F, Lauro N, Rizzi A, eds) Physica Verlag, Heidelberg, 326-331

Mc Adam JH, Hayes P (1981) The effect of shootzone and root-zone temperature on the early growth and development of Zea mays Maris Carmine. Rec Agric Res 29, 39-45 
Messean A (1988) A generalization of GaussMarquardt algorithm for exponential family problems. Comput Stat Q 4, 79-88

Milford GF, Biscoe PV, Jaggard KW, Scott RK, Draycott AP (1980) Physiological potential for increasing yields of sugar beet. In: Opportunities for Increasing Crop Yields (Hurd RG, Biscoe PV, Dennis C, eds) Pitman, London, 710-783

Milford GF, Pocock TO, Riley J (1985a) An analysis of leaf growth in sugar beet. I. Leaf appearance and expansion in relation to temperature under controlled conditions. Ann Appl Biol 106, 163-172

Milford GF, Pocock TO, Jaggard KW, Biscoe PV, Armstrong MJ, Last PJ, Goodmans PJ (1985b) An analysis of leaf growth in sugar beet. IV. The expansion of the leaf canopy in relation to temperature and $\mathrm{ni}$ trogen. Ann Appl Biol 107, 335-347

Misthorpe FL, Moorby J (1974) An Introduction to Crop Physiology. Cambridge Univ Press, Cambridge

Pommel B, Fleury A (1989) Étude de la variabilité individuelle chez le maïs à l'issue de la phase d'installation. Agronomie 9, 467-475
Scott RK, Harper F, Wood DW, Jaggard KW (1974) Effects of seed size on growth, development, and yield of monogerm sugar beet. $J$ Agric Sci Camb 82, 517-530

Scott RK, Jaggard KW (1978) Theoretical criteria for maximum yield. Proc 41st Winter Congr IISBR, Brussels, 179-198

Seber GAF, Wild CJ (1989) Nonlinear Regression. John Wiley, New York

Snyder FW, Carlson GE, Silvius JE, Brunce JA (1979) Selecting for taproot to leaf-weight ratio and its effect on yield and physiology. J Am Soc Sugar Beet Technol 20, 386-396

Watson DJ (1952) The physiological basis of variation in yield. Adv Agron 4, 101-145

Watts WR (1973) Soil temperature and leaf expansion in Zea mays. Exp Agric 9, 1-8

de Wit CT, van Laar HH, van Keulen H (1979) Physiological potential of crop production. In: Plant Breeding Perspectives (Sneep JS, Hendriksen AJT, eds) Pudoc Wageningen, 47-81 